\title{
Bifidobacterial strains in the intestines of newborns originate from their mothers
}

\author{
Hiroshi MAKINO1 \\ ${ }^{1}$ Yakult Central Institute, 5-11 Izumi, Kunitachi-shi, Tokyo 186-8650, Japan \\ Received May 17, 2018; Accepted July 28, 2018; Published online in J-STAGE August 10, 2018
}

The gastrointestinal tract is believed to be colonized rapidly with bacteria immediately from birth. The source of these intestinal microbes is an ongoing topic of interest because increasing evidence suggests that the composition of the initial intestinal bacterial colonization strongly affects health. In particular, the source of bifidobacteria has received marked attention because these bacteria are suggested to play a crucial role in protecting against susceptibility to diverse diseases later in life. However, the source of these microbes has remained unclear. Recently, it was confirmed that mothers transmit their unique bifidobacterial strains to their children shortly after birth. The transmitted strains predominate during early infancy, suggesting that maternal intestinal bifidobacteria are an important source of the infant gut microbiota. Accordingly, maintenance of a healthy, balanced gut microbiota during pregnancy has an important positive influence on the newborn gut microbiota.

Key words: bifidobacteria, human milk, infancy, intestinal microbiota, mother-to-infant transmission

\section{INTRODUCTION}

The intestinal microbiota is a complex ecosystem with extensive metabolic activity; it comprises more than 1,000 bacterial species and accounts for $10^{11}$ to $10^{12}$ bacterial cells per gram of feces $[1,2]$. These bacterial species are considered to play a role in their host's health and disease states by protecting against pathogens, processing nutrients, regulating fat storage, and stimulating angiogenesis [3-6]. The composition of the adult human intestinal microbiota is thought to be stable over a long period, although it can differ markedly among individuals [7]. In contrast, the gastrointestinal tract in infants is rapidly colonized with bacteria immediately after birth [8-10]; the composition of the intestinal microbiota is comparatively simple during breastfeeding, becomes complex after weaning starts, and remains stable into old age [11]. Accumulating evidence suggests that the initial intestinal colonization provides a vast microbial stimulus that leads to profound changes in the development of the gut and the mucosal immune system $[12,13]$. Therefore, microbial colonization during infancy is thought to be essential for a lifetime of good health.

Bifidobacteria are among the most important and beneficial bacteria in the intestine, not only for adults but also for infants. Generally, bifidobacteria become the predominant microorganisms in the intestine within a week after birth,

Corresponding author. Hiroshi Makino (E-mail: hiroshi-makino@, yakult.co.jp)

(C)2018 BMFH Press

This is an open-access article distributed under the terms of the Creative Commons Attribution Non-Commercial No Derivatives (by-nc-nd) License. (CC-BY-NC-ND 4.0: https://creativecommons.org/licenses/by-nc-nd/4.0/) and they remain dominant until weaning [11]. Moreover, bifidobacteria seem to play a crucial role in protecting the host against pathogenic bacteria by helping to prime the mucosal immune system and consequently protecting against susceptibility to diverse diseases later in life [14].

Little information is available regarding the source of these intestinal bacteria. Bifidobacterium species are classified as typical anaerobic bacteria [15], and it has been hypothesized that the infant's intestinal microbes are acquired during transit through the birth canal [16]. Several studies have reported the isolation of Bifidobacterium species_-including $B$. adolescentis, B. bifidum, B. breve, B. catenulatum, and B. longum - from vaginal swabs $[17,18]$. However, little is known about the growth environment in the birth canals of pregnant women and the composition of the vaginal microbiota. Therefore, the origin of these intestinal microbes continues to draw attention.

Several recent studies using strain-level analyses have confirmed that mothers transmit their unique bifidobacterial strains to their infants shortly after birth [19-21]. In this review, I summarize those studies that have investigated the relationships between the maternal intestinal microbiota, the infant intestinal microbiota, and human breast milk.

\section{MATERNAL INTESTINAL BIFIDOBACTERIA AND INFANT INTESTINAL BIFIDOBACTERIA}

Several studies employing molecular biological techniques have suggested the possibility of intestinal microbiota being transmitted from mother to infant [18, 22-25]. The molecular methods used in those studies, such as real-time quantitative PCR (qPCR), are effective in identifying microorganisms at the species level but do not allow comparisons at the 


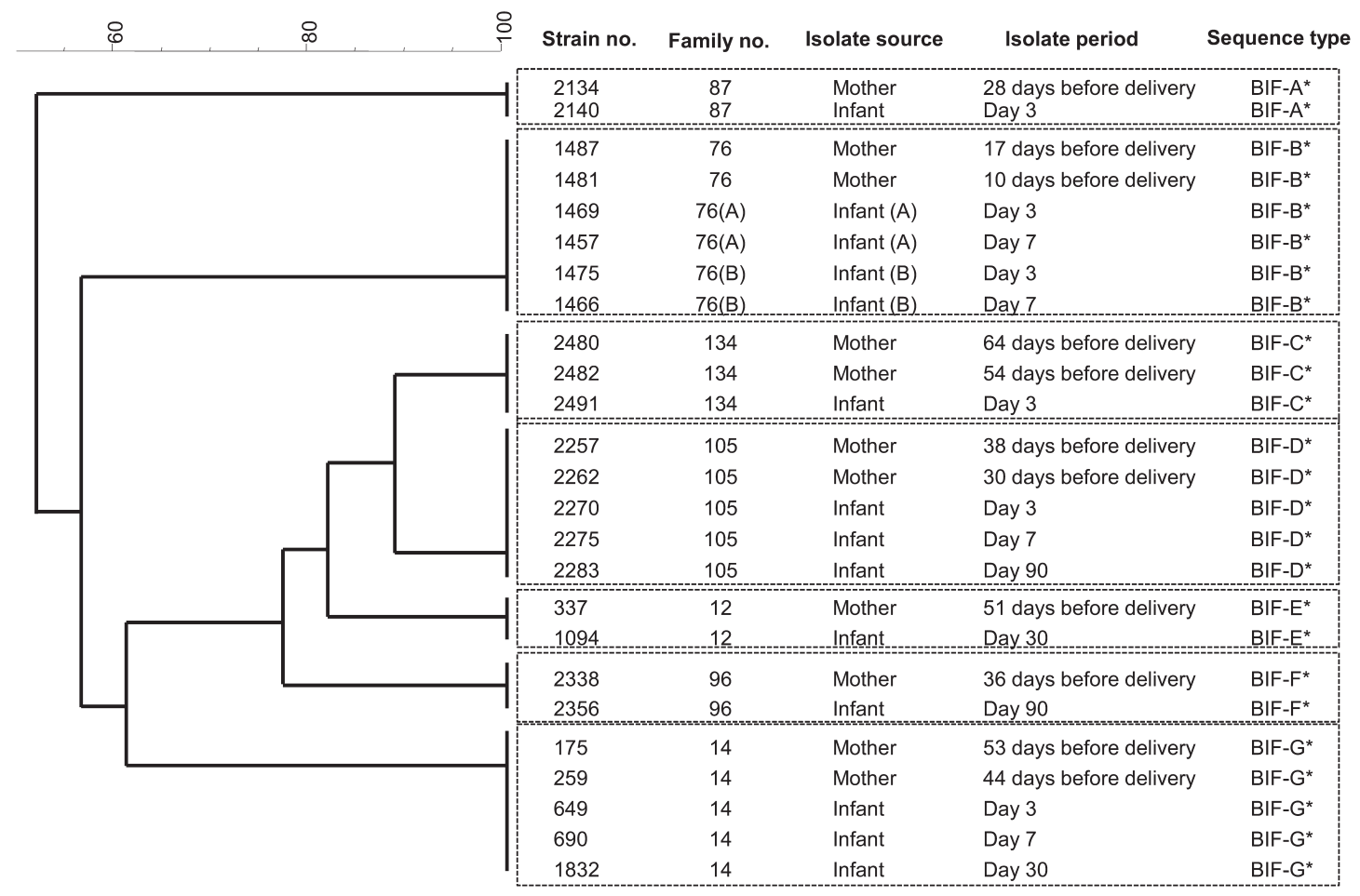

Fig. 1. Dendrogram of 25 individual B. bifidum strains (BIF) (modified from the study by Makino et al. [21]). *Isolates from both members of a mother-infant pair shared the same sequence type and cluster. Note that mother No. 76 gave birth to twins (A, B). The original publication is available at https://doi.org/10.1371/journal.pone.0078331.

strain level. Moreover, randomly amplified polymorphic DNA (RAPD) and pulsed-field gel electrophoresis (PFGE) analyses have been questioned as highly sensitive strain-level typing techniques due to factors in their basic designs that can potentially produce spurious bands [26, 27]. Therefore, further, more highly sensitive analyses are required to confirm what, when, and how bacteria are transferred from the mother or any other environmental sources to the infant.

Makino et al. investigated the relationship between maternal intestinal bifidobacteria and infant intestinal bifidobacteria by using multilocus sequence typing (MLST) $[19,20]$. MLST uses sequence polymorphisms of a set of seven genes in the genome to generate data that can be used to differentiate between bacterial strains [28]. This method yields high-resolution, reproducible data and is, therefore, suitable for both species identification and strain typing [29].

Bifidobacterial strains were isolated from fecal samples that were collected from 17 healthy mother-infant pairs (vaginal delivery, 12 pairs; cesarean delivery, 5 pairs), living in Antwerp (Belgium) [20]. Fecal samples were taken from the mothers twice (at least 1 week apart) before delivery and from the infants at 0 (meconium), 3, 7, 30, and 90 days of age. Bifidobacterial strains were isolated from these samples and categorized by using MLST. In total, 273 bifidobacterial isolates were obtained, and five Bifidobacterium species (B. adolescentis, $B$. bifidum, $B$. catenulatum, $B$. longum subspecies longum, and $B$. pseudocatenulatum) were found to be monophyletic between individual mother and infant pairs. These findings confirmed that mother-to-infant transmission of several Bifidobacterium species occurs. Mother-infant monophyletic strains were continuously detected over time in the infant fecal samples (Fig. 1). These results suggested that the predominant strains in the intestines of the pregnant mothers were transferred to the intestines of their infants, increased in numbers soon after birth, and subsequently colonized the infants. These findings confirmed the initial studies that suggested the importance of mother-to-infant transmission of bacteria in the colonization of the gastrointestinal tract of neonates [22-25]. Moreover, in several families, two strains from different species were monophyletic, confirming that mother-to-infant transmission of several Bifidobacterium species can occur in parallel within a single family. These results further suggest that other commensal bacterial species might also be transmitted from the mother and colonize the intestine of the infant soon after birth.

Mother-infant monophyletic Bifidobacterium strains were obtained from 11 of 12 vaginally born infants (Table 1). Of note, monophyletic Bifidobacterium strains were not observed among the five infants delivered by $\mathrm{C}$-section, verifying that mother-to-infant transmission of these strains occurred only among the vaginally born infants. These results suggest that the delivery mode may influence the occurrence of mother-toinfant transmission. 
Table 1. Detection of mother-infant monophyletic Bifidobacterium strains among 17 mother-infant pairs (modified from the study by Makino et al. [21])

\begin{tabular}{|c|c|c|c|c|c|c|c|}
\hline \multirow{2}{*}{$\begin{array}{l}\text { Mode of } \\
\text { delivery }\end{array}$} & \multirow{2}{*}{\multicolumn{2}{|c|}{ Family no. }} & \multicolumn{5}{|c|}{ Mother-infant monophyletic Bifidobacterium strains obtained from mother-infant pairs } \\
\hline & & & B. adolescentis & B. bifidum & B. catenulatum & B. longum subsp. longum & B. pseudocatenulatum \\
\hline \multirow[t]{12}{*}{ Vaginal } & & 12 & & $\bullet$ & & & \\
\hline & & 14 & & $\bullet$ & & & \\
\hline & & 16 & $\bullet$ & & & $\bullet$ & \\
\hline & & 66 & & & & & \\
\hline & 76 & $\operatorname{Twin}(\mathrm{A})^{\mathrm{a}}$ & & $\bullet$ & & & \\
\hline & 10 & Twin $(B)^{a}$ & $\bullet$ & $\bullet$ & & & \\
\hline & & 87 & & $\bullet$ & $\bullet$ & & \\
\hline & & 96 & & $\bullet$ & & & $\bullet$ \\
\hline & & 105 & & $\bullet$ & & & \\
\hline & & 87 & & & & $\bullet$ & $\bullet$ \\
\hline & & 121 & $\bullet$ & & & $\bullet$ & \\
\hline & & 134 & & $\bullet$ & & $\bullet$ & \\
\hline Cesarean & & $\begin{array}{l}10 \\
19 \\
30 \\
31 \\
48\end{array}$ & & & & & \\
\hline
\end{tabular}

Isolation of at least one mother-infant monophyletic Bifidobacterium strain from a family is indicated by a filled circle $(\bullet)$.

${ }^{a}$ Mother No. 76 gave birth to twins (A, B).

The original publication is available at https://doi.org/10.1371/journal.pone.0078331.

The bifidobacterial counts of the monophyletic strain species were analyzed by qPCR. Among vaginally delivered infants, mother-infant monophyletic strain species in the intestines increased in number to become the predominant Bifidobacterium strains within 3 days of birth. In contrast, among infants delivered via $\mathrm{C}$-section, the total number of bifidobacteria remained significantly lower than those for vaginally delivered infants until 7 days of age. This finding offers confirmatory evidence that intestinal colonization with bifidobacteria starts earlier among vaginally delivered infants than among those delivered by $\mathrm{C}$-section [30]. Among infants born vaginally, the increase in the number of bifidobacteria within a few days of birth may be correlated with the occurrence of mother-to-infant transmission. Moreover, given that mother-infant monophyletic strains were not observed in infants delivered via C-section, the maternal strains were likely transmitted during transit through the birth canal.

Interestingly, not all mother-infant monophyletic Bifidobacterium strains were isolated throughout the sampling period. Mother-infant monophyletic B. bifidum and $B$. longum subsp. longum strains were isolated from the infant fecal samples for as long as 90 days after birth. The bacterial count showed that these were the predominant Bifidobacterium species from 3 until 90 days after birth (Fig. 2). In contrast, monophyletic strains belonging to $B$. adolescentis and B. catenulatum were not found in the infant fecal samples after 7 days of age. Moreover, although several vaginally delivered infants harbored these species at concentrations as high as $10^{10}$ cells/g of feces, these species were not dominant in the intestines of vaginally delivered infants during early infancy. These results suggest that some bifidobacterial species predominantly proliferate in, and colonize, the guts of vaginally delivered infants.

All infants in the study were exclusively breastfed for at least 2 months. It is widely known that human milk contains a variety of complex oligosaccharides (HMOs) that selectively stimulate the growth of specific bifidobacterial species [31, 32]. Typical infant species such as $B$. bifidum and $B$. longum effectively utilize HMOs [33-35], whereas adult-type bifidobacteria such as $B$. adolescentis are less efficient in utilizing HMOs [34, 35]. Therefore, breastfeeding and the presence of HMOs may be key factors that explain why, despite infants acquiring a wide spectrum of bifidobacterial species from their mothers, the species that are able to utilize HMOs remain as some of the predominant colonizers of the infant gut.

Several studies have suggested that environment factors, such as the presence of hospital staff or other infants, may also influence the composition of the intestinal microbiota [36-38]. Using plasmid profiling, Murono et al. found that hospital strains of Escherichia coli were transmitted horizontally among infants [38]. On the other hand, Makino et al. showed that none of the monophyletic bifidobacterial strains were identified in other infants born in the same hospital, and they found no evidence for the occurrence of horizontal transmission of bifidobacteria [20]. Moreover, mother-infant monophyletic strains of all five of the Bifidobacterium species 


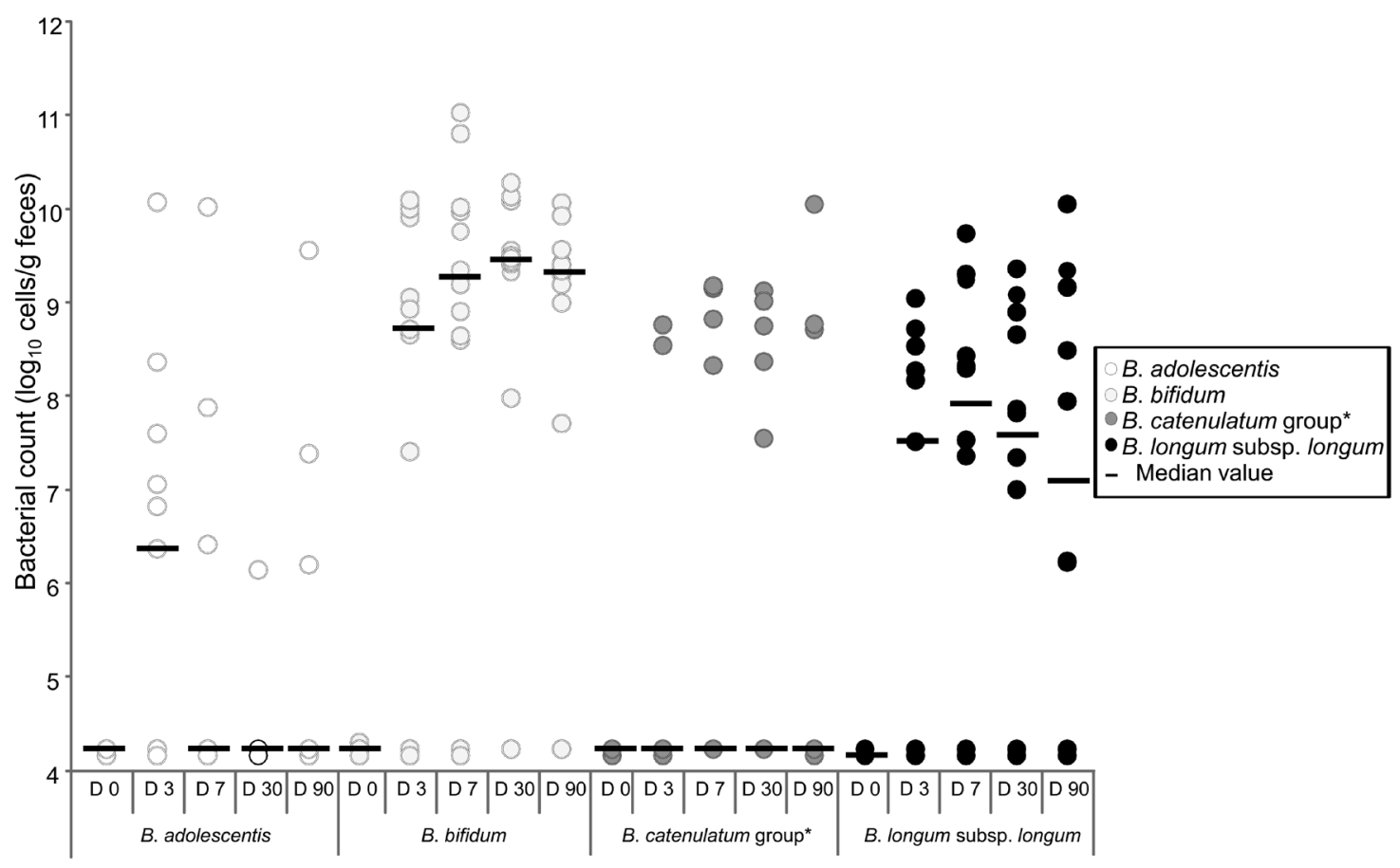

Fig. 2. Counts of each Bifidobacterium species in feces of infants aged 0 to 90 days (modified from the study of Makino et al. [21]). *The B. catenulatum group comprises species of B. catenulatum and B. pseudocatenulatum. The original publication is available at https://doi.org/10.1371/journal.pone.0078331.

formed individual clusters for each family, suggesting that each family had its own unique bifidobacterial group that was transmitted from mother to infant. This vertical transfer concept is strengthened by the fact that Bifidobacterium strains from a mother who gave birth to twins were identified in the intestines of both infants (Fig. 1), suggesting that the host genetic background may also be a key factor that influences the composition of the intestinal microbiota. This is in agreement with the findings of previous studies reporting that each family harbors its own set of Lactobacillus and Bifidobacterium species [39, 40]. Taken together, these findings indicate that the delivery mode and the intestinal bifidobacterial strains of the mother are key determinants of the infant bifidobacterial microbiota during early infancy.

\section{INFANT INTESTINAL BIFIDOBACTERIA AND BIFIDOBACTERIA IN HUMAN BREAST MILK}

It has been suggested that bacteria from the human maternal gut reach the milk via the so-called entero-mammary pathway and thereby influence the colonization of the infant gut [41, 42]. Previous studies have demonstrated that strains of $B$. breve and $B$. longum subsp. longum found in the feces of human infants are identical to the strains found in their mother's milk $[19,43,44]$. Those studies hypothesized that there is vertical transmission of $B$. breve strains from maternal milk to infant, because $B$. breve strains were found to be monophyletic between the human milk and the infant gut within the same mother-infant pairs [43, 44]. However, given that detailed time series data of the isolates (including isolation periods) were not published in those studies, the question remains as to whether these shared bifidobacteria were transiently present or whether they colonized the infant's gut.

Makino et al. investigated whether the sharing of bifidobacterial strains between maternal milk and the infant gut is sustained over the period of breastfeeding [21]. In their study, 283 bifidobacterial strains were isolated from maternal human milk and infant feces collected at various time points from 102 healthy mother-infant pairs (for human milk, once before delivery, at delivery [colostrum], and at 7 and 30 days after delivery; for infant feces, at birth [meconium] and at 7 and 30 days of age). Isolates were identified by $16 \mathrm{~S}$ rRNA gene sequencing and classified by using MLST. Bifidobacterial strains were obtained from human milk collected at 7 and 30 days after delivery, and in agreement with previous studies $[45,46]$, the most commonly isolated Bifidobacterium species was $B$. breve. In contrast, no bifidobacteria were isolated from any of the human milk samples taken before delivery or from colostrum. On the other hand, isolation from infant feces was confirmed sometimes as early as the day of birth (meconium).

Interestingly, strains belonging to infant-type bifidobacteria such as B. breve, B. longum subsp. longum, and B. bifidum species were the only species to be identified as monophyletic between infant feces and maternal milk. These strains were 
Table 2. Timing of the isolation of each monophyletic Bifidobacterium strain from maternal human milk and infant feces (modified from the study by Makino et al. [22])

\begin{tabular}{|c|c|c|c|c|c|c|}
\hline \multirow{2}{*}{ Species } & \multirow{2}{*}{ Sequence type } & \multirow{2}{*}{ Family no. } & \multirow{2}{*}{ Isolate source } & \multicolumn{3}{|c|}{ Time after delivery } \\
\hline & & & & Day 0 & Day 7 & Day 30 \\
\hline \multirow[t]{6}{*}{ B. bifidum } & \multirow[t]{2}{*}{ BIF-A } & \multirow[t]{2}{*}{105} & Human milk & - & $\bullet$ & $\bullet$ \\
\hline & & & Infant feces & - & $\bullet$ & \\
\hline & \multirow[t]{2}{*}{ BIF-B } & \multirow[t]{2}{*}{12} & Human milk & - & - & $\bullet$ \\
\hline & & & Infant feces & - & - & $\bullet$ \\
\hline & \multirow[t]{2}{*}{ BIF-C } & \multirow[t]{2}{*}{14} & Human milk & - & - & $\bullet$ \\
\hline & & & Infant feces & - & $\bullet$ & $\bullet$ \\
\hline \multirow[t]{22}{*}{ B. breve } & \multirow[t]{2}{*}{ BRE-A } & \multirow[t]{2}{*}{20} & Human milk & - & - & $\bullet$ \\
\hline & & & Infant feces & - & $\bullet$ & $\bullet$ \\
\hline & \multirow[t]{2}{*}{ BRE-B } & \multirow[t]{2}{*}{28} & Human milk & - & $\bullet$ & $\bullet$ \\
\hline & & & Infant feces & - & $\bullet$ & $\bullet$ \\
\hline & \multirow[t]{2}{*}{ BRE-C } & \multirow[t]{2}{*}{130} & Human milk & - & $\bullet$ & - \\
\hline & & & Infant feces & - & $\bullet$ & - \\
\hline & \multirow[t]{2}{*}{ BRE-D } & \multirow[t]{2}{*}{54} & Human milk & - & - & $\bullet$ \\
\hline & & & Infant feces & - & - & - \\
\hline & \multirow[t]{2}{*}{ BRE-G } & \multirow[t]{2}{*}{87} & Human milk & - & $\bullet$ & $\bullet$ \\
\hline & & & Infant feces & - & $\bullet$ & $\bullet$ \\
\hline & \multirow[t]{2}{*}{ BRE-H } & \multirow[t]{2}{*}{121} & Human milk & - & - & - \\
\hline & & & Infant feces & - & $\bullet$ & $\bullet$ \\
\hline & \multirow[t]{2}{*}{ BRE-I } & 32 & Human milk & - & - & $\bullet$ \\
\hline & & & Infant feces & - & - & $\bullet$ \\
\hline & BRE-L & 105 & Human milk & - & - & $\bullet$ \\
\hline & & & Infant feces & - & - & $\bullet$ \\
\hline & BRE-M & $76(\mathrm{~A})$ & Human milk & - & - & $\bullet$ \\
\hline & & & Infant feces & - & - & $\bullet$ \\
\hline & & $76(\mathrm{~B})$ & Human milk & - & - & $\bullet$ \\
\hline & & & Infant feces & - & - & - \\
\hline & BRE-N & 96 & Human milk & - & - & $\bullet$ \\
\hline & & & Infant feces & - & $\bullet$ & $\bullet$ \\
\hline B. longum subsp. & LON-A & 134 & Human milk & - & - & - \\
\hline longum & & & Infant feces & - & $\bullet$ & $\bullet$ \\
\hline & LON-B & 134 & Human milk & - & - & $\bullet$ \\
\hline & & & Infant feces & - & $\bullet$ & $\bullet$ \\
\hline & LON-C & 8 & Human milk & - & - & $\bullet$ \\
\hline & & & Infant feces & $\bullet$ & $\bullet$ & - \\
\hline & LON-F & 18 & Human milk & - & $\bullet$ & - \\
\hline & & & Infant feces & - & $\bullet$ & $\bullet$ \\
\hline & LON-G & 129 & Human milk & - & $\bullet$ & $\bullet$ \\
\hline & & & Infant feces & $\bullet$ & - & $\bullet$ \\
\hline
\end{tabular}

Isolation of at least one monophyletic Bifidobacterium strain from a sample is indicated by a filled circle $(\bullet)$. Non-shaded cells indicate families in which the earliest isolation of monophyletic strains was on the same day for both the infant feces and human milk.

Shaded cells indicate families in which the monophyletic strains were isolated earlier from the infant feces than from human milk.

Mother No. 76 gave birth to twins (A, B).

The original publication is available at https://doi.org/10.3920/BM2014.0082.

continuously detected in the mother's milk and infant feces throughout the period of breastfeeding, confirming that they were sustainably shared between the maternal milk and the infant gut. Moreover, the monophyletic strains were isolated from infant feces at time points the same as, or earlier than, when they were isolated from human milk; none were isolated 
earlier from human milk than from infant feces (Table 2). Therefore, these results do not support those of previous reports that suggested that bifidobacteria are transmitted from human milk to the infant gut $[41,42,45,46]$. In fact, the results of the study of Makino et al. suggest that bifidobacterial strains are transmitted from the infant to human milk during breastfeeding, given that infrared photography has revealed a high degree of retrograde flow back into the mammary ducts during suckling [47]. The probability of strain transmission from infant to human milk was significantly higher than from human milk to infant [21].

Because of the limitations of the methodology used by Makino et al. (i.e., the inherent bias that arises from the culture methods used), it remains unclear whether human milk is the first source of microbes for infants. However, the results confirm that human milk is a reservoir of bifidobacteria and that specific strains are shared between the infant intestine and human milk during breastfeeding.

\section{CONCLUDING REMARKS AND OUTLOOK}

Recent studies have confirmed that mothers who give birth vaginally transmit their unique, family-specific bacterial strains to the intestines of their infants during early infancy. These data suggest that the delivery mode and the maternal intestinal bifidobacterial strains are key factors in determining the infant bifidobacterial microbiota during early infancy. Maintenance of a healthy, balanced intestinal microbiota during pregnancy is an important factor that positively influences the newborn's intestinal microbiota. Factors such as nutrition in infants may influence the persistence of familyspecific bifidobacterial strains in infants. Further advanced strain-level investigations will clarify how mother-to-infant transmission influences other components of the intestinal microbiota during infancy and hence the importance of the maternal gut, birth canal, and milk in the colonization of the neonate gut.

\section{PRESENTATION AT A CONFERENCE}

The contents of this article received the 2017 Japan Bifidus Foundation Research Encouragement Award and were presented at the Japan Bifidus Foundation's 22nd Annual Meeting of Intestinal Microbiology (May 31-June 1, 2018 , Tokyo, Japan).

\section{ACKNOWLEDGEMENTS}

This work was supported by Yakult Central Institute, Yakult Honsha European Research Center for Microbiology ESV, and Danone Nutricia Research. I am deeply grateful to all concerned for giving me the opportunity to receive the Japan Bifidus Foundation Research Encouragement Award.

\section{REFERENCES}

1. Eckburg PB, Bik EM, Bernstein CN, Purdom E, Dethlefsen L, Sargent M, Gill SR, Nelson KE, Relman DA. 2005. Diversity of the human intestinal microbial flora. Science 308: 1635-1638. [Medline] [CrossRef]

2. Qin J, Li R, Raes J, Arumugam M, Burgdorf KS, Manichanh C, Nielsen T, Pons N, Levenez F, Yamada T, Mende DR, Li J, Xu J, Li S, Li D, Cao J, Wang B, Liang H, Zheng H, Xie Y, Tap J, Lepage P, Bertalan M, Batto JM, Hansen T, Le Paslier D, Linneberg A, Nielsen HB, Pelletier E, Renault P, Sicheritz-Ponten T, Turner K, Zhu H, Yu C, Li S, Jian M, Zhou Y, Li Y, Zhang X, Li S, Qin N, Yang H, Wang J, Brunak S, Doré J, Guarner F, Kristiansen K, Pedersen O, Parkhill J, Weissenbach J, Bork P, Ehrlich SD, Wang J, Wang J, MetaHIT Consortium. 2010. A human gut microbial gene catalogue established by metagenomic sequencing. Nature 464 : 59-65. [Medline] [CrossRef]

3. Adlerberth I, Lindberg E, Aberg N, Hesselmar B, Saalman R, Strannegård IL, Wold AE. 2006. Reduced enterobacterial and increased staphylococcal colonization of the infantile bowel: an effect of hygienic lifestyle? Pediatr Res 59: 96-101. [Medline] [CrossRef]

4. Fanaro S, Chierici R, Guerrini P, Vigi V. 2003. Intestinal microflora in early infancy: composition and development. Acta Paediatr Suppl 91: 48-55. [Medline]

5. Ley RE, Peterson DA, Gordon JI. 2006. Ecological and evolutionary forces shaping microbial diversity in the human intestine. Cell 124: 837-848. [Medline] [CrossRef]

6. Ley RE, Turnbaugh PJ, Klein S, Gordon JI. 2006. Microbial ecology: human gut microbes associated with obesity. Nature 444: 1022-1023. [Medline] [CrossRef]

7. Faith JJ, Guruge JL, Charbonneau M, Subramanian S, Seedorf H, Goodman AL, Clemente JC, Knight R, Heath AC, Leibel RL, Rosenbaum M, Gordon JI. 2013. The long-term stability of the human gut microbiota. Science 341: 1237439. [Medline] [CrossRef]

8. Gosalbes MJ, Llop S, Vallès Y, Moya A, Ballester F, Francino MP. 2013. Meconium microbiota types dominated by lactic acid or enteric bacteria are differentially associated with maternal eczema and respiratory problems in infants. Clin Exp Allergy 43: 198-211. [Medline] [CrossRef]

9. Jiménez E, Marín ML, Martín R, Odriozola JM, Olivares M, Xaus J, Fernández L, Rodríguez JM. 2008. Is meconium from healthy newborns actually sterile? Res Microbiol 159: 187-193. [Medline] [CrossRef]

10. Favier CF, de Vos WM, Akkermans AD. 2003. Development of bacterial and bifidobacterial communities in feces of newborn babies. Anaerobe 9: 219-229. [Medline] [CrossRef]

11. Mitsuoka T, Hayakawa K, Kimura N. 1974. [The faecal flora of man. II. The composition of bifidobacterium flora of different age groups (author's transl)]. Zentralbl Bakteriol [Orig A] 226: 469-478 (In German). [Medline]

12. Lundell AC, Björnsson V, Ljung A, Ceder M, Johansen S, Lindhagen G, Törnhage CJ, Adlerberth I, Wold AE, Rudin A. 2012. Infant B cell memory differentiation and early gut bacterial colonization. J Immunol 188: 4315-4322. [Medline] [CrossRef]

13. Olszak T, An D, Zeissig S, Vera MP, Richter J, Franke A, Glickman JN, Siebert R, Baron RM, Kasper DL, Blumberg RS. 2012. Microbial exposure during early life has persistent effects on natural killer T cell function. Science 336: 489-493. [Medline] [CrossRef]

14. Turroni F, Ribbera A, Foroni E, van Sinderen D, Ventura M. 2008. Human gut microbiota and bifidobacteria: from composition to functionality. Antonie van Leeuwenhoek 94: 35-50. [Medline] [CrossRef]

15. Tannock GW. 1999. Identification of lactobacilli and bifidobacteria. Curr Issues Mol Biol 1: 53-64. [Medline]

16. Inoue R, Ushida K. 2003. Vertical and horizontal transmission of intestinal commensal bacteria in the rat model. FEMS Microbiol Ecol 46: 213-219. [Medline] [CrossRef]

17. Verhelst R, Verstraelen H, Claeys G, Verschraegen G, Van Simaey L, De Ganck C, De Backer E, Temmerman M, Vaneechoutte M. 2005. Comparison between Gram stain and culture for the characterization of vaginal microflora: definition of a distinct grade that resembles grade I microflora and revised categorization of grade I microflora. BMC Microbiol 5: 61. [Medline] [CrossRef]

18. Mikami K, Takahashi H, Kimura M, Isozaki M, Izuchi K, Shibata R, Sudo N, Matsumoto H, Koga Y. 2009. Influence of maternal bifidobacteria on the establishment of bifidobacteria colonizing the gut in infants. Pediatr Res 65 : 669-674. [Medline] [CrossRef]

19. Makino H, Kushiro A, Ishikawa E, Muylaert D, Kubota H, Sakai T, Oishi K, Martin R, Ben Amor K, Oozeer R, Knol J, Tanaka R. 2011. Transmission of intestinal Bifidobacterium longum subsp. longum strains from mother to infant, determined by multilocus sequencing typing and amplified fragment length 
polymorphism. Appl Environ Microbiol 77: 6788-6793. [Medline] [CrossRef]

20. Makino H, Kushiro A, Ishikawa E, Kubota H, Gawad A, Sakai T, Oishi K, Martin R, Ben-Amor K, Knol J, Tanaka R. 2013. Mother-to-infant transmission of intestinal bifidobacterial strains has an impact on the early development of vaginally delivered infant's microbiota. PLoS One 8: e78331. [Medline] [CrossRef]

21. Makino H, Martin R, Ishikawa E, Gawad A, Kubota H, Sakai T, Oishi K, Tanaka R, Ben-Amor K, Knol J, Kushiro A. 2015. Multilocus sequence typing of bifidobacterial strains from infant's faeces and human milk: are bifidobacteria being sustainably shared during breastfeeding? Benef Microbes 6: 563-572. [Medline] [CrossRef]

22. Kijima A, Umekawa N, Yoshida M, Osawa R. 2010. PFGE analysis and aerobic and microaerophilic survival of Bifidobacterium longum subsp. longum isolated from feces of human mother-infant pairs. Chonai Saikingaku Zasshi 24: 293-302 (In Japanese)

23. Albesharat R, Ehrmann MA, Korakli M, Yazaji S, Vogel RF. 2011. Phenotypic and genotypic analyses of lactic acid bacteria in local fermented food, breast milk and faeces of mothers and their babies. Syst Appl Microbiol 34: 148-155. [Medline] [CrossRef]

24. Matsumiya Y, Kato N, Watanabe K, Kato H. 2002. Molecular epidemiological study of vertical transmission of vaginal Lactobacillus species from mothers to newborn infants in Japanese, by arbitrarily primed polymerase chain reaction. J Infect Chemother 8: 43-49. [Medline] [CrossRef]

25. Takahashi H, Mikami K, Nishino R, Matsuoka T, Kimura M, Koga Y. 2010 Comparative analysis of the properties of bifidobacterial isolates from fecal samples of mother-infant pairs. J Pediatr Gastroenterol Nutr 51: 653-660. [Medline] [CrossRef]

26. Rabouam C, Comes AM, Bretagnolle V, Humbert JF, Periquet G, Bigot Y. 1999. Features of DNA fragments obtained by random amplified polymorphic DNA (RAPD) assays. Mol Ecol 8: 493-503. [Medline] [CrossRef]

27. Carriço JA, Pinto FR, Simas C, Nunes S, Sousa NG, Frazão N, de Lencastre H, Almeida JS. 2005. Assessment of band-based similarity coefficients for automatic type and subtype classification of microbial isolates analyzed by pulsed-field gel electrophoresis. J Clin Microbiol 43: 5483-5490. [Medline] [CrossRef]

28. Ventura M, Canchaya C, Del Casale A, Dellaglio F, Neviani E, Fitzgerald GF, van Sinderen D. 2006. Analysis of bifidobacterial evolution using a multilocus approach. Int J Syst Evol Microbiol 56: 2783-2792. [Medline] [CrossRef]

29. Delétoile A, Passet V, Aires J, Chambaud I, Butel MJ, Smokvina T, Brisse S. 2010. Species delineation and clonal diversity in four Bifidobacterium species as revealed by multilocus sequencing. Res Microbiol 161: 82-90. [Medline] [CrossRef]

30. Biasucci G, Benenati B, Morelli L, Bessi E, Boehm G. 2008. Cesarean delivery may affect the early biodiversity of intestinal bacteria. J Nutr 138: 1796S-1800S. [Medline] [CrossRef]

31. Sela DA, Mills DA. 2010. Nursing our microbiota: molecular linkages between bifidobacteria and milk oligosaccharides. Trends Microbiol 18: 298-307. [Medline] [CrossRef]

32. Zivkovic AM, German JB, Lebrilla CB, Mills DA. 2011. Human milk glycobiome and its impact on the infant gastrointestinal microbiota. Proc Natl Acad Sci USA 108 Suppl 1: 4653-4658. [Medline] [CrossRef]

33. Asakuma S, Hatakeyama E, Urashima T, Yoshida E, Katayama T, Yamamoto K,
Kumagai H, Ashida H, Hirose J, Kitaoka M. 2011. Physiology of consumption of human milk oligosaccharides by infant gut-associated bifidobacteria. J Biol Chem 286: 34583-34592. [Medline] [CrossRef]

34. Locascio RG, Niñonuevo MR, Kronewitter SR, Freeman SL, German JB, Lebrilla CB, Mills DA. 2009. A versatile and scalable strategy for glycoprofiling bifidobacterial consumption of human milk oligosaccharides. Microb Biotechnol 2: 333-342. [Medline] [CrossRef]

35. Xiao JZ, Takahashi S, Nishimoto M, Odamaki T, Yaeshima T, Iwatsuki K, Kitaoka M. 2010. Distribution of in vitro fermentation ability of lacto- $N$-biose I, a major building block of human milk oligosaccharides, in bifidobacterial strains. Appl Environ Microbiol 76: 54-59. [Medline] [CrossRef]

36. Mitsuoka T, Kaneuchi C. 1977. Ecology of the bifidobacteria. Am J Clin Nutr 30: 1799-1810. [Medline] [CrossRef]

37. Fryklund B, Tullus K, Berglund B, Burman LG. 1992. Importance of the environment and the faecal flora of infants, nursing staff and parents as sources of gram-negative bacteria colonizing newborns in three neonatal wards. Infection 20: 253-257. [Medline] [CrossRef]

38. Murono K, Fujita K, Yoshikawa M, Saijo M, Inyaku F, Kakehashi H, Tsukamoto T. 1993. Acquisition of nonmaternal Enterobacteriaceae by infants delivered in hospitals. J Pediatr 122: 120-125. [Medline] [CrossRef]

39. McCartney AL, Wenzhi W, Tannock GW. 1996. Molecular analysis of the composition of the bifidobacterial and lactobacillus microflora of humans. Appl Environ Microbiol 62: 4608-4613. [Medline]

40. Odamaki T, Bottacini F, Kato K, Mitsuyama E, Yoshida K, Horigome A, Xiao JZ, van Sinderen D. 2018. Genomic diversity and distribution of Bifidobacterium longum subsp. longum across the human lifespan. Sci Rep 8: 85. [Medline] [CrossRef]

41. Perez PF, Doré J, Leclerc M, Levenez F, Benyacoub J, Serrant P, Segura-Roggero I, Schiffrin EJ, Donnet-Hughes A. 2007. Bacterial imprinting of the neonatal immune system: lessons from maternal cells? Pediatrics 119: e724-e732. [Medline] [CrossRef]

42. Martín R, Langa S, Reviriego C, Jiménez E, Marín ML, Olivares M, Boza J, Jiménez J, Fernández L, Xaus J, Rodríguez JM. 2004. The commensal microflora of human milk: new perspectives for food bacteriotherapy and probiotics. Trends Food Sci Technol 15: 121-127. [CrossRef]

43. Jost T, Lacroix C, Braegger C, Chassard C. 2013. Assessment of bacterial diversity in breast milk using culture-dependent and culture-independent approaches. $\mathrm{Br} \mathrm{J}$ Nutr 110: 1253-1262. [Medline] [CrossRef]

44. Martín V, Maldonado-Barragán A, Moles L, Rodriguez-Baños M, Campo RD Fernández L, Rodríguez JM, Jiménez E. 2012. Sharing of bacterial strains between breast milk and infant feces. J Hum Lact 28: 36-44. [Medline] [CrossRef]

45. Jost T, Lacroix C, Braegger CP, Rochat F, Chassard C. 2014. Vertical motherneonate transfer of maternal gut bacteria via breastfeeding. Environ Microbiol 16: 2891-2904. [Medline] [CrossRef]

46. Solís G, de Los Reyes-Gavilan CG, Fernández N, Margolles A, Gueimonde M 2010. Establishment and development of lactic acid bacteria and bifidobacteria microbiota in breast-milk and the infant gut. Anaerobe 16: 307-310. [Medline] [CrossRef]

47. Ramsay DT, Kent JC, Owens RA, Hartmann PE. 2004. Ultrasound imaging of milk ejection in the breast of lactating women. Pediatrics 113: 361-367. [Medline] [CrossRef] 